\title{
Serotonergic Antidepressants as Predictors of Depressive Disorders Treatment
}

\author{
Ivana P. Timotijević ${ }^{1}$, Mirjana M. Todorovićc ${ }^{2}$ Katarina B. Crnić ${ }^{2}$, \\ Srdjan Z. Marković ${ }^{3}$, Dragana A. Kastratović ${ }^{4}$ \\ 1 "Euromedik" Polyclinic, School of Medicine, University of Belgrade, Belgrade, Serbia; \\ ${ }^{2}$ Clinic "Ramah", Belgrade, Serbia; \\ ${ }^{3}$ School of Medicine, University of Belgrade, Belgrade, Serbia; \\ ${ }^{4}$ Clinical Center of Serbia, Belgrade, Serbia
}

\section{SUMMARY}

From Kraepelin time to these days, biochemical, neurophysiological and neuropsychological complexity of depression has been reviewed in many different ways, but SSRI antidepressants have unquestionably brought about a significant drift in comprehension of disease, recognition of symptoms, and management.

The fact is that high tech and accurate molecular studies may differentiate biological basis (receptor activity, transmitter concentrations not only in synapses, but also in particular CNS structures, cascade processes to changes of genomes in postsynaptic neurons) of some depression symptoms. It is a significant progress in overview of psychiatric disorders because any symptom has its equivalent in CNS processes as antidepressants have their recognizable mechanisms of action. In this dynamic drug/disease relation, standard psychiatric classifications maintain their significance yet their approach remains descriptive what is no longer enough for selection of psychopharmacotherapy.

Abandonment of categorical and adoption of dimensional approach means that any individual patient has his individual symptom portfolio created and that every symptom is hypothetically mapped in appropriate CNS structures and corresponding impaired information processes, dependent upon neurotransmitter pathways within these structures and connecting neuronal networks. Such approach opens up a possibility for combination of psychopharmacological drugs in different psychiatric categories what will be a huge benefit for patients, because targeted psychopharmacotherapy adjusts therapeutical effect and reduces the number of side effects and intolerable interactions.

SSRI antidepressants, due to their broad spectrum of pharmacological characteristics and multiple psychiatric indications may be predictors of diagnostic categorization, causal psychopharmacotherapy and path to further research of etiopathogenesis of affective disorders.

Keywords: SSRI antidepressants; amygdaloid nucleus; hippocampus; prefrontal cortex; depressive cluster 


\section{INTRODUCTION}

Serotonergic antidepressants as rarely as any other medications have dramatically changed psychopharmacology, and since their discovery and beginning of their application in the late 1980s they have become the most prescribed drugs in psychiatry, a field of mental health and primary healthcare, with broad therapeutic indications both for psychiatric disorders and other medical fields, such as cardiology, pulmonology, dermatology and endocrinology.

SSRI antidepressants are a part of heterogenous groups of psychopharmacological drugs. They are defined as pharmacological substances acting on neurotransmitter nuclei, pathways and receptors in CNS structures connected with mood and emotion regulation and specific behavior equivalents in health and sickness.

Antidepressant mechanism of action encourages and enhances the biological theory of affective disorders, which associates affective disorders with the dysfunction of serotonergic, noradrenergic and dopaminergic neurotransmitter systems in a specific, dynamic relation. Their action is manifested through the increase of synaptic activity and process in corresponding receptors and neurons of specific CNS structures. The result of antidepressant activity is an improvement of emotional symptoms, mood, other syndromes and psychiatric disorders within the affective domain.

\section{SEROTONERGIC ANTIDEPRESSANTS}

First generation (FGA), so-called "classical" antidepressants, discovered in 1950s includes irreversible MAO inhibitors and tricyclic antidepressants, which are still in use due to their clinical efficacy, but associated with the risk of serious side effects.

Second generation (SGA), or "new" antidepressants, discovered and developed in 1980s involves pharmacologically more selective drugs, with specific action to one or more neurotransmitter systems and appropriate receptors, with clinically significant efficacy and improved safety profile. They are mostly divided to serotonergic (SSRI), and noradrenergic (NARI) ones, with the associated mechanism of action (NaSSA) and other mechanisms of action. Research on new substances with potential antidepressive action, targeting at serotonin receptors and causing, by indirect mechanisms, the increase of other neurotransmitter levels, as well as the substances testing other biological theories of affective disorders (substance P antagonists, glucocorticoid and corticotrophin releasing factor antagonists and vasopressin antagonists), all of them presuppose future antidepressants.

The most significant and most commonly used antidepressants in practice are, as above mentioned, the class of serotonin selective reuptake inhibitors - SSRIs, with predominant effect on serotonergic system. Their pharmacological action takes place in serotonin transporter on presynaptic membrane of serotonergic neurons (SERT), blocking the reuptake of serotonin in presynaptic neuron and increasing the amount of available serotonin in the synaptic cleft and on postsynaptic receptors. Antidepressive action is explained by monoamine hypothesis on etiopathogenesis of depression, which is basically a change of number or sensitivity of serotonin receptors on the neuronal membranes, impaired synthesis of key cell-survival proteins and disorder of gene expression [1].

The increase of serotonin amount in postsynaptic receptors, caused by drug effect, induces a series of cascade processes in the neuron. As the first messenger, 5-HT opens ion channels or activates $G$ protein, what leads to activation of enzymatic systems, cyclic AMP, adenyl cyclase and phosphoinositol system. The second and the third messenger are formed, with final consequences in modulation of gene expression, receptor synthesis and key proteins. Depending on neurotransmitter signaling, the genome modulation transmits, at different velocity and duration, the impact to other surrounding neurons, thus producing the network of genome changes. During this process, the brain-derived neurotrophic factor (BDNF) is being activated. In homeostasis, BDNF maintains the vitality of neurons, while gene repression and its deficit may be stress-induced, leading to atrophy and apoptosis of hippocampal neurons. The increase of available serotonin on synapses in the key CNS structures for emotional functioning reverses this process and normalizes BDNF quantity. Neuroprotective and neurotrophic effects of antidepressants are based on intraneuronal changes of CREB protein and BDNF synthesis, resulting in varying genome modulations, what has been verified by neuroimaging study findings on the size of hippocampus in pre- and post-treated depressed patients [2]. 
SSRI class includes six key antidepressants. Other than mutual effect on serotonin reuptake inhibition (SRI), each of them is featured by a spectrum of specific characteristics, assuming not only affinity for serotonin but also for other neurotransmitter systems, receptors and enzymes, what consequently determines desired therapeutical and adverse effects.

Fluoxetine is able to act on dopaminergic and noradrenergic systems as noradrenaline reuptake inhibitor (NRI) and 5HT2C receptor antagonist, respectively, increasing the release of dopamine and noradrenaline in the cortex, and accordingly, augmenting its therapeutic efficacy. 5HT2C antagonism accounts for its favorable effect in nutritional disorder. It is inhibitor of the cytochrome P450 liver enzyme (CYP2D6 and CYP 3A4), what must be taken into consideration in concomitant use of other drugs [3].

Paroxetine acts as noradrenaline reuptake inhibitor (NRI), what increases its therapeutic efficacy in depression, especially when higher doses are administered, and its action on muscarinic receptors $\mathrm{M} 1$ and anticholinergic action account for its potent anxiolytic characteristics. It is considered that anticholinergic rebound is predominantly responsible for noticeable withdrawal syndrome in sudden discontinuation of drugs. The inhibition of nitric oxide synthetase (NOS) affects sexual dysfunction, and its effect on cytochrome P450 liver enzyme, CYP2D6, calls for attention in combination with other drugs.

Sertraline acts as dopamine reuptake inhibitor (DRI) what enriches and increases its therapeutic efficacy, as well as atypical cluster of depression symptoms. Action on sigma 1 receptor explains its anxiolytic effect and favorable effect on psychotic depression symptoms.

Fluvoxamine has a potential effect on sigma 1 receptor ("sigma enigma"), what allows for its effect on anxiety and psychotic symptoms. It also affects cytochrome P450 enzymatic system, CYP3A4 and CYP1A2.

Citalopram consists of two enantiomers, $R$ and $\mathrm{S}$. Enantiomer R has mild antihistaminic action via $\mathrm{H} 1$ receptor, what provides favorable anxiolytic effect, and its effect on cytochrome P450 enzymatic system, CYP2D6 is moderate, so it is often recommended for depression therapy in geriatric population because it is well tolerated.

Escitalopram is a $\mathrm{S}$ citalopram, mirror image of $\mathrm{R}$ enantiomer, but with moderately different clinical effect and different effect on serotonergic transporter. Among SSRIs antidepressants, it is known as most selective reuptake serotonin blocker, with no other effects and extremely favorable safety profile with high therapeutic efficacy [4].

The majority of SSRIs antidepressants, other than serotonergic reuptake inhibition (SRI), has noradrenaline reuptake inhibition (NRI) and dopamine reuptake inhibition (DRI). SSRIs antidepressants have effect, in varying degree, on other receptors, antagonistically to $5 \mathrm{HT} 2 \mathrm{C}$ receptors, antagonistically to muscarinic-cholinergic receptors (M1), histaminic (H1) and sigma 1 receptors [5]. In addition, they have inhibitory effect on nitric oxide synthetase (NOS), cytochrome P450, CYP2D6, CYP3A4 and CYP1A2, causing the gastrointestinal and neurological side effects as well as sexual dysfunction. Versatility of SSRIs effects cover different symptoms, which are manifested in syndromes of psychiatric disorders frequently beyond simplified diagnoses. Due to well tolerability and safety, and associated with mild or moderate side effects subsiding already after one-week treatment, they are rarely the reason for discontinuation of therapy. In those having effect on cytochrome P450 enzymatic system, one should be cautious in concomitant use of other drugs.

\section{DEPRESSION AND DEPRESSION BEHAVIORAL EQUIVALENTS}

Basic therapeutic indication for serotonergic antidepressants (SSRI) is unipolar depression, along with numerous expanded indications as in psychiatric disorders - anxiety disorders [6], nutritional disorder, impaired impulse and aggression control in personality disorders, and other conditions such as myocardial infarction, diabetes, bronchial asthma and neurodermatitis.

New paradigm on understanding and management of psychiatric disorders is the knowledge of where the disorders and drugs affect specific neurons and molecules in the brain and neuronal network, as well as the best way to choose and combine medicaments that may achieve not only reduction but also qualitative and long-term remission of psychiatric disorder symptoms in an individual patient. 


\section{CNS STRUCTURES RESPONSIBLE FOR DEPRESSION SYMPTOMS}

Numerous modern and available imaging techniques confirmed earlier theories on structures related with the specific forms of behavior and psychiatric disorders [7]. The central place is taken by limbic cortex structures - amygdaloid nuclei, hypothalamus, hippocampus, basal ganglia structures (nucleus accumbens, striatum), dorsal and ventral prefrontal cortex. All of them are interconnected by multiple neuronal networks wherein different neurotransmitters transfer the impulses. Neurotransmitter serotonergic nodi are primarily found in raphe nuclei of the brainstem from where their axons are spread towards higher brain structures [8]. Genesis of emotions, particularly fear and anxiety, and the control of stress and mood are mostly connected with amygdaloid nucleus and ventral prefrontal cortex where serotonergic system activity is predominant [9]. Therefore, hypothetically, dysfunction of these regions and their regulating neurotransmitters takes the central part in etiopathogenesis of affective disorders. Moreover, it is considered that serotonergic system and its multiple projections are related with the anxiety disorders, obsessive-compulsive disorder, and nutritional disorder. Naturally, the impact of other structures and neurotransmitter system cannot be neglected, what has a special significance in prescription of adequate medication [10].

Core symptoms of depression, such as depressive mood disorder, are associated with the inefficient information processing in amygdala and ventromedial prefrontal cortex (VMPFC), both innervated by serotonergic, noradrenergic and dopaminergic projections from brainstem nuclei. Reduced, dysfunctional and insufficient monoaminergic functioning in these regions results in depression mood [2].

Sleep and appetite disorders, feeling of guilt or worthlessness, suicidal ideas, are associated with the amygdaloid nucleus, hypothalamus, hippocampus and ventral prefrontal cortex, i.e. predominantly with the serotonergic system. Depression and sleep and appetite disorders are also in relation with the action of noradrenergic and dopaminergic systems, what accounts for favorable effects of serotonergic and noradrenergic antidepressants on these symptoms.

Lack of satisfaction, interest and will is the result of inefficient information processing diffusely through the prefrontal cortex (PFC) as well as in hypothalamic centers (Hy) and the nucleus accumbens (NA). These functions within the prefrontal cortex and hypothalamus are thought to be regulated in part by noradrenergic neurons, while within prefrontal cortex, hypothalamus, and nucleus accumbens these functions are also thought to be regulated by dopaminergic projections [2].

Cognitive disorders, psychomotor retardation or agitation as well as fatigue are attributed to dysfunction of nucleus accumbens, striatum and dorsal prefrontal cortex, i.e. noradrenergic and dopaminergic systems. These facts should be considered if these symptoms prevailed in the clinical picture, or appeared as residual, what would be generally more common if SSRI antidepressants were used in treatment.

\section{DISCUSSION ON DEPRESSION SYMPTOMS MAPPING}

Different pharmacological profiles of antidepressants indicate sophisticated and individualized medication for individually treated patients with specific symptoms of psychiatric disorders $[11,12]$. This is the reason why abovementioned approach to treatment of depressive disorders has been recommended. Deconstruction of pertinent symptoms of depression in any individual patient enables the mapping of such symptoms in an appropriate brain structure, which is regulated by one or more neurotransmitter system as well as application of such drug or combination of drugs which will have effect on appropriate neurotransmitter systems and their dysfunction-related symptoms, thus providing adequate and long-term remission of depression. It is supposed that it will be possible in future to have insight, by routine imaging techniques, in dysfunctional brain structures and pathways, to check diagnoses and effects of medication, what is today actually carried out in clinical studies and accordingly on a smaller number of subjects. Referring again to serotonergic antidepressants, it is definitely clear that this approach, within existing 6 groups, lead to more reliable decision-making on the use of adequate drug for an individual patient and achievement of better results in prognostic and therapeutical aspect.

Numerous placebo-controlled and evidence-based studies as well as rich clinical experience have proven their equally high efficacy in reduction and cure of typical depression symptoms, what is based on their essential effect on 
increasing the amount of available serotonin in serotonergic system synapses. However, many differences in individual patient's response to different kinds of SSRIs suggest that their action on other neurotransmitter systems and receptors may be used for treatment of atypical depression symptoms, which often make depression of certain patients difficult to cure, followed by residual symptoms and incomplete remission, tendency towards chronicity and resistance to therapy [13].

If optimal effect is desired in a patient with typical depression symptomatology and increased body weight or comorbid bulimia, an optimal option will be fluoxetine. It will be also a drug of choice for management of BAP depressive phase in combination with olanzapine given the synergistic effect of both drugs as $5 \mathrm{HT} 2 \mathrm{C}$ receptor antagonists.

In depressive patient with the atypical symptom cluster, sertraline will be more appropriate, which will also be a drug of choice for the anxiety-depressive disorder and depression with the psychotic symptoms. Citalopram is recommended for management of older population due to its tolerability, and Escitalopram due to its potent antidepressive effect on typical depressive cluster and good safety profile. Escitalopram is therefore recommended in cardiological conditions (myocardial infarction), and in therapy, prevention and reduction of stress-induced risk of aggravation. Medicaments suitable for combination with other drugs, in so-called "liaison" psychiatry, Fluvoxamine and Paroxetine have become, for their specific profile, rather the drugs used for management of anxiety disorders than for depression, except when prescribed in higher doses.

\section{CONCLUSIONS}

SSRIs antidepressants are the first line of treatment of all guidelines and algorhythms of good clinical practice and possible predictors of treatment of depression disorders. Recent studies do not imply that such position of theirs will be left to some other antidepressants with different mode of action.

The relation of clinical diagnostics and SSRI antidepressant therapy is rather dynamic than straight-line, meaning that not only diagnosis conditions the use of specific drug but also the success of treatment has feedback impact on diagnosis and frequently to possibility of differential diagnosis. Some depression symptoms coincide with the symptoms of other psychiatric disorders, i.e. early stages of dementia, when the use of SSRIs and success/non-success of management resolves diagnostic dilemma between pseudodepression and pseudodementia.

Modern holistic approach and new psychopharmacological doctrine evade stereotype and routine utilization of drugs, and make ideal of causal treatment of psychiatric disorders closer. Not only the approach to psychopharmacology changes, but diagnostic approach is different as well.

Abandonment of categorical and adoption of dimensional approach means that any individual patient has his individual symptom portfolio created and that every symptom is hypothetically mapped in appropriate CNS structures and corresponding impaired information processes, dependent upon neurotransmitter pathways within these structures and connecting neuronal networks.

\section{Conflict of Interest Statement}

The authors certify that there are no potential conflicts of interest.

\section{REFERENCES}

1. Rakic Ignjatovic A, Miljkovic B, Todorovic D, Timotijevic I, Pokrajac M. Moclobemide monotherapy vs combined therapy with valproic acid or carbamazepine in depressive patients: a pharmacokinetic interaction study. Br J Clin Pharmacol. 2009; 67:199-208.

2. Stahl SM. Stahl's Essential Psychopharmacology. 3rd ed. New York, NY: Cambridge University Press; 2008.

3. Vezmar S, Miljkovic B, Vucicevic K, Timotijevic I, Prostran M, Todorovic Z, et al. Pharmacokinetics and efficacy of fluvoxamine and amitriptyline in depression. J Pharmacol Sci. 2009; 110:98-104.

4. Quesseveur G, Reperant C, David DJ, Gardier AM, Sanchez C, Guiard BP. 5-HT2A receptor inactivation potentiates the acute antidepressant-like activity of escitalopram: involvement of the noradrenergic system. Exp Brain Res. 2013; 226(2):285-95.

5. Hanon J, Hoyer D. Molecular biology of 5-HT receptors. Behavior Brain Res. 2008; 195:198 213.

6. Shin LM, Liberzon I. The neurocircuitry of fear, stress, and anxiety disorders. Neuropsychopharmacology. 2010; 35(1):196-91.

7. Gilbertson MW, Stenton ME, Ciszewatski A. Smaller hippocampal volume predicts pathological vulnerability to psychological trauma. Nat Neurosci. 2002; 5(11):1242-7.

8. Berger M, Gray JA, Roth BL. The expanded biology of serotonin. Annu Rev Med. 2009; 60:355-66. 
9. Timotijević I, Stanković Ž, Todorović M, Marković SZ, Kastratović DA. Serotonergic organization of the central nervous system. Psychiat Danub. 2012; 24 Suppl 3:S326-30.

10. Artigas F. Future directions for serotonin and antidepressants. ACS Chem Neurosci. 2013; 4(1):5-8.

11. Ignjatovic AR, Miljkovic B, Todorovic D, Timotijevic I, Pokrajac M. Evaluation of single-point sampling strategies for the estimation of moclobemide exposure in depressive patients. J Clin Pharmacol. 2011; 51(5):661-71.
12. Janković SM, Timotijević I, Mihajlović GS, Dukić-Dejanović S. Comparison of two approaches to amitriptyline dose individualisation. Eur J Drug Metab Pharmacokinet. 1999; 24(2):163-8.

13. Timotijević IP, Todorović MM, Crnić KB, Marković SZ, Kastratović DA. Affective spectrum disorders and role of serotonergic system of the brain. Hospital Pharmacology - International Multidisciplinary Journal. 2014 [in press].

\title{
Serotonergički antidepresivi kao prediktori lečenja depresivnih poremećaja
}

\author{
Ivana P. Timotijević ${ }^{1}$, Mirjana M. Todorović ${ }^{2}$, Katarina B. Crnić2 \\ Srđan Z. Marković ${ }^{3}$, Dragana A. Kastratović ${ }^{4}$ \\ ${ }^{1}$ Poliklinika „Euromedik“, Medicinski fakultet Univerziteta u Beogradu, Beograd, Srbija; \\ ${ }^{2}$ Klinika „Ramah“, Beograd, Srbija; \\ ${ }^{3}$ Medicinski fakultet Univerziteta u Beogradu, Beograd, Srbija; \\ ${ }^{4}$ Klinički centar Srbije, Beograd, Srbija
}

\section{KRATAK SADRŽAJ}

Od vremena Krepelina (Kraepelin) do danas biohemijska, neurofiziološka i neuropsihološka kompleksnost depresije razmatrana je na mnogo različitih načina, ali SSRI antidepresivi su nedvosmisleno doveli do značajnog pomaka u razumevanju ove bolesti, prepoznavanju simptoma i njihovom rešavanju.

Činjenica je da visoka tehnologija i precizne molekularne studije mogu da diferenciraju biološku osnovu (aktivnost receptora, koncentraciju transmitera ne samo u sinapsama, već i u određenim strukturama centralnog nervnog sistema, kaskadne procese u promenama genoma u postsinaptičkim neuronima) nekih simptoma depresije. To je značajan napredak u sagledavanju psihijatrijskih oboljenja, zato što svaki simptom ima ekvivalent u procesima centralnog nervnog sistema, kao što antidepresivi imaju svoj prepoznatljivi mehanizam dejstva. U ovom dinamičkom odnosu leka i bolesti standardne klasifikacije psihijatrijskih oboljenja zadržavaju i dalje svoj značaj, ali njihov pristup ostaje deskriptivan, što više nije dovoljno pri izboru psihofarmakoterapije.

Napuštanje kategorijalnog i usvajanje dimenzionalnog pristupa znači da se za svakog pojedinačnog bolesnika izrađuje individualni portfolio simptoma i da se svaki simptom hipotetički mapira u odgovarajuće strukture centralnog nervnog sistema i odgovarajuće narušene informacione procese, u zavisnosti od neurotransmiterskih puteva u okviru ovih struktura i povezujućih neuralnih mreža. Ovakav pristup otvara mogućnost za kombinovanje psihofarmakoloških lekova u različitim psihijatrijskim kategorijama, što će bolesnicima biti veoma korisno, jer se ciljnom psihofarmakoterapijom podešava terapijski efekat, a smanjuju broj neželjenih dejstava i nedozvoljene interakcije.

SSRI antidepresivi, zbog svog širokog spektra farmakoloških svojstava i brojnih psihijatrijskih indikacija, mogu da budu prediktori kategorizacije dijagnoza, uzročne psihofarmakoterapije i put ka daljem istraživanju etiopatogeneze afektivnih poremećaja.

Ključne reči: SSRI antidepresivi; amigdaloidno jedro; hipokampus; prefrontalni korteks; klaster depresivnih simptoma 